\title{
ET FASCINERENDE UDSTILLINGSKATALOG OVER INDUSTRIALISERINGENS MANGE FORTOLKNINGER
}

Geoffrey Cantor (red.):

The Great Exibition: A Documentary History, bind 1-4

Pickering \& Chatto, 2013

1776 sider, $£ 350$

Den store verdensudstilling i London i 1851, eller The Great Exhibition of the Works of All Nations, som den fulde titel lød, er måske en af de mest ikoniske begivenheder i videnskabens, teknologiens og industriens historie. Det vurderes at der, i løbet af de 141 dage udstillingerne var åbne for publikum i det til lejligheden opførte Crystal Palace, gik ikke mindre end 6 millioner mennesker igennem billetlugen, mere end 100.000 besøgende på de travleste dage. I standardfortællingen bliver denne store udstilling, som skulle blive en af de mest kendte $i$ en lang række af lignende internationale begivenheder, udlagt som teknikkens og videnskabens store sejrsfest; som briternes manifestation af deres industrielle og økonomiske overmagt. Udstillingen er ligeledes blevet beskrevet som en overvejende sekulær begivenhed, hvor videnskaben og industrien beviste sine evner til at samle menneskeden på tværs af nationaliteter og kontinenter.

The Great Exibition: A documentary history er en enormt omfangsrig samling af primær kildemateriale fra planlægningen, afviklingen og modtagelsen af verdensudstillingen. Hermed har den britiske videnskabshistoriker Geoffrey Cantor frembragt en eminent kilde til at fortælle en langt mere nuanceret historie, ikke bare om denne ene verdensbegivenhed, men om hvilke betydninger videnskab, teknologi og industri kunne have i midten af 1900tallet, i England i særdeleshed, men også i Europa mere generelt. I sin oplysende og velskrevne introduktion til samlingen, forklarer Cantor hvordan de traditionelle narrativer som verdensudstillingen normalt sættes ind i, kan føres tilbage til initiativtagerne til udstillingen, Prins Albert, Dronning Victorias ægtefælle, og embedsmanden og opfinderen Henry Cole. De oprindelige forslag og de efterfølgende programskrifter knytter 
kraftigt an til en idé om videnskabelig internationalisme som kommer til udtryk i forestillingen om at denne verdensbegivenhed i videnskabens og industriens navn ville føre til nye stadier af global fred og samhandel, foruden respekt og anerkendelse til Storbritannien. Cole indleder således klart sin introduktionstekst fra det officielle udstillingskatalog med at skrive, at "næppe kunne en udstilling som denne have fundet sted på et tidligere tidspunkt $\mathrm{i}$ historien, og muligvis ikke hos noget andet folk end vores" (1:211). Med en så mangesidig samling fra debatten om formålet og effekterne af at afholde en verdensudstilling, giver Cantor os en mulighed for at dykke ned i en tids videnskabelige diskurs og forfølge alle de tematikker - religiøse, politiske, æstetiske - som ellers let bliver overskygget af det narrativ som arrangørerne, med stor succes, har bidraget til.

Tekstudvalget er inddelt kronologisk i otte sektioner fordelt over de fire tykke bind. Hver sektion er forsynet med en kort introduktion af udvalget, og hvor det er relevant, er teksterne yderligere inddelt $i$ undergrupperinger som Cantor præsenterer og derved placerer i det samtidige kulturelle og intellektuelle landskab. Første bind indeholder dokumenter vedrørende organiseringen af udstillingen samt de første reaktioner på forslaget. Reaktionerne fortsætter ind $\mathrm{i}$ andet bind hvor vi finder henholdsvis nationalistiske, konservative, religiøse og radikale stemmer, som ytrer sig om udsigten til denne aldrig før sete begivenhed. Protesterne hørtes allerede da udstillingen blev forestået to år forinden, og hele tiden bliver der talt op imod arrangørernes tro på videnskabens civiliserende kraft. Frygten for det fremmede fylder enormt i debatten. Man er bekymret for industrispionage, for invasion af fremmede lande og religioner, samt økonomisk fiasko. Vi finder også strid om beliggenhed i forhold til hvem der bliver begunstiget af de mange udenlandske besøgende man forventede ville komme, og diskussioner om arbejdsforhold blusser op, ligesom patentspørgsmål også rejses. Omvendt er der også dem som udtrykker optimisme i forhold til spredningen af kristendommen. Verdensudstillingen blev nemlig ikke kun set som det sekulære foretagende det senere er blevet tolket som, men kunne i samtiden også læses som et redskab for religionen; som Guds middel til at bringe hedninge til London for at omvende dem. Andet bind forsættes og afsluttes derpå med dokumentation af selve 
åbningsdagen, 1. Maj 1851. Tredje bind indeholder uddrag fra guides til udstillingen, og andet materiale rettet mod de besøgende. Det indeholder også første del af en større samling reaktioner og beretninger fra besøgende under udstillingen, $\mathrm{i}$ form af uddrag fra dagbøger, breve og aviskommentarer skrevet under udstillingen. Øjenvidneberetningerne fortsætter i fjerde og sidste bind med blandt andet udenlandske beretninger. I bind fire får vi en sektion med 15 forskellige samtidige perspektiver eller tolkninger på betydningen af verdensudstillingen. For nogen blev udstillingen tolket som en magtdemonstration og en cementering af den hvide mands overherredømme over resten. For andre åbenbarede udstillingen Storbritanniens position, eller mangel på samme, som den ledende nation indenfor industri, teknologi, design osv. Som generelt for samlingen fornemmes en konstant kamp mellem nationalistiske og internationalistiske tolkninger af verdensudstillingens udbytte. Fjerde bind slutter med dokumentation af afslutningsceremonien og diskussionerne om hvad der efterfølende skulle ske med Joseph Paxtons imponerende bygningsværk Crystal Palace. Cantor har forsynet hele værket med et solidt indeks, samt en fyldig bibliografi over både sekundære og primære titler til videre studier.

Det er klart, at når man laver et udvalg må man også foretage fravalg. Forlaget Pickering \& Chatto kunne, i og for sig, have lavet endnu fire bind bare med eftervirkningerne, og hvilken betydning verdensudstillingen er blevet tilskrevet sidenhen, hvis det var det som var projektet. Styrken ved den meget snævre tidsafgrænsning (fra forslaget først blev fremstillet $\mathrm{i}$ 1849, til refleksionerne over udstillingen af tidens mest indflydelse britiske videnskabsmand William Whewell i 1852) er efter min opfattelse at det giver Cantor mulighed for at give en utrolig tyk beskrivelse af hvad videnskab og teknologi betød i lige netop denne tid.

The Great Exibition: A documentary history er naturligvis ikke tiltænkt en plads på enhver idé- eller videnskabshistoriestuderendes private bogreol. Det er den for nørdet og ikke mindst for dyr til. De fire bind er beregnet til at indgå i forskningsbiblioteker hvor de kan tilgås af alle, fra grundfagsstuderende til forsker, med interesse i forhold som videnskab/samfund, videnskab/historie, videnskab/religion, videnskab/marked eller videnskab/æstetik. I denne 
samling er der stof til utallige universitetsopgaver og jeg vil mene at den vil være mere end egnet til formålet da man her får adgang til ét samlet og utroligt mangesidigt tekstkorpus på en gang. Cantor har gjort et imponerende arbejde ved at samle og præsentere os for en stor del af de stemmer som omgav den ikoniske verdensudstilling i 1851, men det er den efterfølgende forsknings opgave at fortolke det der blev sagt.

Thomas Palmelund Johansen 